done, good and faithful servant," may glorify our awakening.

We render service to the individuals forming the community and the Commonwealth. We ask the community and the Commonwealth to aid us in such service as is beyond our power to render. Is this not a fair request?

I care not how the details are worked out so long as the underlying bases are not disturbed, namely, the establishment of individual need, the freedom of individual action, responsibility placed as required on the individual, the blood relation, the local community or the Commonwealth, the selection of experts free from all extraneous influence.

I do not assume that this is the last word. I believe it to be superior to the plans for Health Insurance that have been proposed. It has closely related with it other problems which it may help to solve. One of these is the question of State aid in maternity work, because, if the difficult cases, early recognized by means of proper prenatal observation, were cared for at the central hospital, the fact of the possibility of this care would stimulate the plans considered for obtaining early the necessary data in obstetric work; and another - that of the rehabilitation of the vocationally disabled - a large field in industrial accident work which is at present only touched upon in its working out, and one which might be developed in connection with the surgical and the electro-physiotherapeutical service at this institution. In matters of detail the plan may be open to argument. In any event, it is offered to you as the conclusion arrived at after a year's special study of the problems involved-a progressive placing of responsibility, with the Commonwealth the culminating factor in rendering ser. vice, otherwise unobtainable, in such a measure as means the highest advantage.

The Commonwealth of Massachusetts has, in the past, always found the members of this Society ready to respond to its call in time of danger or distress, offering service and, if necessary, life. The distress of the poor in time of peace is often nearly as great as in time of war. I am pleading for those who, having neither opportunity nor, perhaps, ability, cannot plead for themselves. In their behalf, I plead with the Commonwealth to give them measures of relief, nor do I think I usurp authority when $I$ say to the Commonwealth,
"I pledge the hearty coöperation and help of the great majority of the physicians of the State in any feasible plan." Service for the Commonwealth and Service by the Commonwealth, is the crux of the "Mutual relation between the physician and the Commonwealth of Massachusetts."

Ainong those to whose courtesy I am indebted in my effort to obtain data for this paper, I am glad to express my appreciation of the aid obtained from Lee Frankel, P.H.D., and Louis I. Dublin, P.H.D, of the Metropolitan Life Insurance Company; Robert Kelso, formerly Commissioner of Public Welfare; George M. Kline, M.D., Commissioner of Mental Diseases; John J. Mitchell, Collector of Internal Revenue; Irving $L$. Shaw, State Income Tax Collector ; Fancis D. Donoghue, M.D., Medical Advisor to the Industrial Accident Board ; Mary E. P. Lowney, Assistant Director to the Industrial Accident Board; Walter P. Bowers, M.D., State Board of Registration in Medicine; Riohard P. Borden of Fall River; Fred Magison of Haverhill; Bertram Bent, Claim Examiner of the Fidelity and Casualty Co.; John H. Nichols, M.D., Superintendent and Mr. Thomas F. Flynn, Treasurer of the State Infirmary. $\longrightarrow$

\section{(Orininal Artirle.}

\section{THE ESSENTIAL FACTORS OF CANCER CAUSATION. \\ By James W. Shannon, M.B., San Diego, Catifrornia. (Continued from page 548)}

According to the Mortality Report of the U. S. Bureau of the Census for the year 1917, the rates and percentages of eancer incidence upon organs and parts of the body are as follows:

\begin{tabular}{|c|c|c|}
\hline & $\begin{array}{l}\text { RATE PER } \\
100,000 \text { POP }\end{array}$ & $\begin{array}{l}\text { PER } \\
\text { CENT. }\end{array}$ \\
\hline Cancer of the buccal cavity ... & 3.0 & 3.7 \\
\hline Cancer of the stomach, liver ... & 31.1 & 38.1 \\
\hline $\begin{array}{l}\text { Cancer of the peritoneum, in tes- } \\
\text { tines, rectum } \ldots \ldots \ldots \ldots \ldots \ldots\end{array}$ & 10.9 & 13.3 \\
\hline $\begin{array}{l}\text { Cancer of the female genital or- } \\
\text { gans } \ldots \ldots \ldots \ldots \ldots \ldots \ldots \ldots \ldots \ldots\end{array}$ & 12.4 & 15.2 \\
\hline Cancer of the breast $\ldots \ldots \ldots$ & 7.6 & 9.3 \\
\hline Cancer of the skin $\ldots \ldots \ldots \ldots$ & 2.9 & 3.5 \\
\hline $\begin{array}{c}\text { Cancer of other organs, or or- } \\
\text { gans not specified } \ldots \ldots \ldots \ldots\end{array}$ & 13.8 & 16.9 \\
\hline
\end{tabular}

These figures show that, whereas 83.1 per cent., or five-sixths, of all cancers appear in structures which together constitute only a small part of the body, namely, in the skin. female breast, and the alimentary and female generative systems, only 16.9 per cent., or onesixth, remain to be distributed among all the other structures of the body. It must be remembered also that, even in those organs which are specially liable to cancerous disease, nearly the whole weight of its attack is borne by certain points which, in comparison to the size of the whole organ, seem to be alnust insignificant. Thus, for instance, the great majority of cancers of the female generative system appear on the cervix uteri; of the alimentary system in 
the region of the pylorus, and of the skin at certain points on the face and hands. Since, in view of these and other similar facts, we cannot doubt that eancer is a local disease or that the conditions present in certain organs or parts of organs are more favorable to its causation than in others, it becomes necessary to consider how and why it happens that the conditions favorable to the causation of the disease are not present in an equal degree in all organs and parts of the body.

From what has been said concerning the rôle of lesions and water in the causation of cancer, it is obvious that the presence of both these factors is a condition common to all parts and organs of the body which become the seat of the disease. If it is true that the causative agent of cancer exists in water and that it gains access to the living cells of the tissues through a lesion in the protective surfaces of the body, it follows that the chances of cancer arising at the site of any lesion depend--other things being equal- -upon the degree of exposure of such lesion to water. Lesions have no inherent tendency to become cancerous, and so long as the protective surfaces of the body are intact water cannot act upon the living cells of the tissies; hence, neither lesions alone nor water alone is able to cause the disease. Cancer results only from the coöperation of lesions and water, and only those conditions which contribute, not to the causations of lesions or to their exposure to water, but to the coöperation of lesions with water, can properly be regarded as its predisposing causes. All conditions, therefore, such as age, sex, habit, custom, occupation, etc., which heretofore have been regarded as predisposing to cancer, are, in a strict sense, predisposing causes not of cancer, but of lesions only. It is only in a few cases, as, for example, x-ray work, when it happens that habit, custom, occupation, etc., perform a double part; firstly, by contributing to the pausation of lesions, and, secondly, by favoring their exposure to water, that they are entitled to be considered as really predisposing to cancerous disease.

More than one-half- 55 per cent.-of all cancers arise in the alimentary system, i.e., in the buccal cavity, stomach, liver, peritoneum, intestines, or rectum, and of these, more than twothirds,-69 per cent.,- - are found in the stomach. It is estimated that cancer of the stomach is three times more frequent than of any other organ or part of the body, and, as the above figures show, gastric cancers constitute more than one-third of all cancers. These facts are undoubtedly remarkable, but it is even more remarkable that, in an overwhelming proportion of cases, the attack of cancer is directed towards one small part of the stomach, namely, the pyloric region. In the absence of reliable data, it is impossible to determine exactly what percentage of cancers are situated in the pyloric area, but inasmuch as 38 per cent. of all cancers arise in the stomach, it is probably not an exaggeration to say that cancer of the pylorus constitutes 30 per cent., or nearly one-third of all cases of cancerous disease throughout the body, and somewhat less than two-thirds of all cancers of the alimentary system. It is, however, a matter of minor importance whether these estimates prove to be justified or not, since in any event the fact remains that the liability of the pyloric region to cancerous disease far exceeds that of any other part of the body, regardless of its size or situation. Other parts of the alimentary system attacked in undue proportion are the buccal cavity, the duodenum and the rectum. Cancers of the pharynx, tsoph agus, intestines, and peritoneum occur comparatively seldom, and primary cancer of the liver and pancreas is rare.

\section{(To be continued.)}

\section{Tonk 解nivur.}

Feebleness of Growth and Congenital Dwarfism. By Dr. Murk Jansen, O. B. E. London: Henry Frowde. Hodder and Stoughton. 1921.

This volume, "Feebleness of Growth and Congenital Dwarfism," is an attempt to work out two main principles : (1) that injurious agents affecting growing cell-groups enfeeble their power of growth: (2) that the measure in which growth is enfeebled is proportional to the rapidity of growth. The author has shown how the similarity between "Rachitis" and "Achondroplasia" may be determined by these principles which account also for other conditions developing before or after birth. The first part of the book deals with growth-changes which develop after birth; the second part considers congenital growth-changes, with which, inasmuch as they are incompatible with extra-uterine life, the practitioner is much less familiar. Anencephaly, achondroplasia, mongoloid, idiocy, dysostoses, cleido-cranialis and congenital clubfoot and congenital dislocation of hip are discussed and are illustrated by many excellent plates. 